\title{
The Dynamics of Cooperation at the Individual Level at Work
}

\author{
I A Silviandari ${ }^{1}$, Faturochman ${ }^{2}, \mathbf{R}$ M Bakar ${ }^{3}$ \\ 1,2 Universitas Gadjah Mada, ${ }^{1}$ Universitas Brawijaya, ${ }^{3}$ Universitas Negeri Makassar \\ 1.ika.adita.s@mail.ugm.ac.id, ${ }^{2}$ faturpsi@ugm.ac.id, ${ }^{3}$ resekiani, masbakar@unm.ac.id
}

\begin{abstract}
Focus of this research was the exploration of the dynamics of cooperation at the individual level at work. A qualitative method with a constructive realism approach was chosen for this research to find and construct the realities (the world of life) in lay community groups related to their understanding of cooperation in workplace. Data collection was carried out using the open questionnaire method for 140 employees from various sectors and the data were analyzed using content analysis techniques. The results showed that cooperation at the individual level in workplace settings is a dynamic relation among the dimensions of relationship quality, competence, consequence, work facilitation and emotions. Cooperation at the individual level started from the relationship between individuals which is manifested in the form of togetherness, involvement, understanding of others, reciprocal behavior and respect. These positive behaviors can encourage the emergence of self- competencies that support the achievement of consequences in the form of task accomplishments and material achievements. Through these achievements cooperation can facilitate work to be light, easy and run smoothly. In this research, the end of the dynamics of cooperation is the emergence of emotional aspects, namely positive emotions, emotional regulation and emotional stability. This aspect arised because it is influenced by work facilitation and consequences.
\end{abstract}

Keywords: cooperation, individual level, dinamics

\section{INTRODUCTION}

Cooperation is an important and fundamental thing in human life. People's beliefs about how their goals of cooperation are achieved, will determine how individuals work together with others. The fundamental principle in cooperation is that individual goals will only be achieved if the goals of others are also achieved [1]. This is what can encourage the emergence of mutual trust, exchange of resources, and mutual assistance in ongoing efforts [2]. From this process a relationship is formed that characterizes openness, positive things and productivity [3]. Over the years, both academics and practitioners have recognized that cooperation is crucial for organizational success [4] .

Cooperation is the study of behavioral science rooted in social interdependence theory. At the beginning of its development, the theory of cooperation was formulated by Deutsch in 1940 as the development of Kurt Lewin's great thought about the theory of social interdependence. 
There are two types of social interdependence, positive and negative. Positive social interdependence will lead to effective actions and promotive patterns of interaction that can provide outcomes in the form of effort to achieve, quality of relationship, and psychological health. Whereas negative interdependence will result in bugling actions and contrient interaction patterns [5]. In the era of the 2000s, many new perspectives on cooperation were associated with justice, one of the researchers concerned in this case was Tyler and Blader. According to them, teamwork is defined as a decision regarding the actions of team members whether to promote team goals or not. Tyler and Blader explained that there are two ways of working together: first, proactive actions promote team effectiveness, for example, providing assistance, contributing ideas voluntarily, and exchanging information. Second, the act of refraining from behavior that impedes team effectiveness, for example, does not use team resources for personal gain. Referring to the explanation of Tyler and Blader, cooperation is defined as a form of mutual facilitation [6]

Research on cooperation has been carried out in many countries and cultures. In North America (United States, Canada, Mexico), for example, studies have been conducted with the participant population of Caucasian, Black American, Native American, and Hispanics. In addition, cooperation has been researched in Asia (for example, Japan, Hong Kong, China, South Korea, India), Southeast Asia (for example, including Australia and New Zealand, Singapore, Malaysia, Thailand), the Middle East (for example, Saudi Arabia, Iran, Jordan, United Arab Emirates, Israel, Turkey), Africa (for example, Nigeria, South Africa), Europe (for example, Greece, Norway, Sweden, Finland, Germany, France, Netherlands, United Kingdom), Ireland, Italy, Switzerland, Czech Republic), and many other countries [5]. However, to this extent, reality shows that there are no studies that have developed the concept of cooperation in contextual work settings in Indonesia. This is important because in addition to conceptualizing the construct of cooperation that has not been defined contextually, Indonesia is also an effort to centralize the development of local Indonesian elements or concentricity [7]

Therefore, based on this background in this paper the researcher put his research point of view on two main points. First, cooperation is a multilevel concept. When referring to Deutsch's thought, as Johnson \& Johnson said [8] that cooperation can occur between two aspects of individuals (intrapersonal), between individuals (interpersonal), between groups (organizational), between regions of a country or the world (between regions), between cultures (inter cultural), between nations (international), and even among other species. Second, cooperation is a part of social interdependence that is inseparable from the influence of local culture [9] [10], and a researcher is not possible to understand and explain social phenomena in a society without including their cultural context, because each culture can only be understood by using the cultural reference itself [11]. Therefore, this research was conducted using the Indigenous Psychology approach. This approach is a study of knowledge, skills, values and beliefs that people have about themselves and the ways they perform functions in their original context so that they can reflect the real reality [6]

Besides conceptually, there are many reasons why this collaboration is very important in practice, especially for long-term organizational effectiveness. First, cooperation between group members can ensure that group efforts will be coordinated towards a common goal, thus enabling the group to take more effective actions [12]. In addition, [13] argue that cooperative behavior can directly increase the productivity of group members. Furthermore, collaboration can promote the efficient use of group resources. If within a group only pursue individual or sub-group goals it will 
be able to undermine the overall success of the group either directly by diverting resources or indirectly by weakening the determination or desire of other group members to continue to voluntarily make efforts on behalf of the group [14]. When seen in everyday life and in the life of an organization is often in the encounter that many individuals work in groups together in a room and the same workspace, but they don't have the orientation or the same purpose with one another, so that the performance from the group is ineffective and many aspects of the group are inhibited. Therefore the purpose of this study is to answer research questions, how cooperation dynamics occur at the individual level at work?

\section{RESEARCH METHOD}

This research is a preliminary study to find the concepts and dynamics of cooperation in work settings, so the method used in this research is a qualitative method using the constructive realism approach. Constructive realism explained that reality has three levels, namely actuality or wichlichkeit, the world of life (lifeworld), and the micro world [6] . In this study, researchers conducted explorative studies to find and construct realities (lifeworld) in lay community groups related to their understanding of the cooperation carried out in the workplace. After lifeworld construction, microworld construction will continue. Microworld construction is usually done by scientists. The final result to be achieved at this stage is the identification of the themes forming the concepts and dynamics of cooperation in work settings.

\subsection{Research Participants}

This research used qualitative methods. According to Creswell, qualitative methods do not have the aim to generalize research results. Therefore the selection of participants is carried out in such a way as to explain what would be needed in accordance with the objectives of the study[15]. The characteristics of the first participant are employees who work in the Makassar area and beyond. Second, the minimum age is 19 years.

\subsection{Data collection technique}

An open ended questionnaire was used to collect data in this study. The intended use of the open-ended questionnaire was to explore the meaning of the participants against the consequences of cooperation both at the individual level and organizations, so that researchers can draw up concepts, constructs, and components of the consequences of the cooperation on the work setting. The number of participants in this study were 140 people who were employees from various sectors (banking, manufacturing, education, hospitality, etc.). The main question in the open ended questionnaire is what is the outcome of the cooperation for you?

\subsection{Data analysis technique}

Data from the open ended questionnaire were analyzed using content analysis techniques. The analysis that has been carried out is a multiple response analysis, because all participants in 
this study put forward more than one reason when describing his experience in establishing cooperation with one of his coworkers.

The analysis is carried out with the initial stage of compiling transcripts of open answers from participants and giving a number for each answer. Furthermore, researchers read over and over the text or response responses that have been given by participants to get an overall impression of the data and find keywords and organize them into different meaning units according to their contents. Then proceed with synthesizing each unit of meaning into the theme, categorizing based on the similarity of meaning of the theme, arranging the main categories or components and exploring the interrelations between themes.

\section{RESULT AND DISCUSSION}

The first step taken by researchers to discover the dynamics of cooperation at the individual level is through the process of identifying themes. The process of identifying themes is carried out with content analysis techniques on the participants' answers by giving them the name of the theme or concept that accommodates the initial theme (sub-themes) found from the keywords. The keywords that have the same meaning are categorized into one theme, starting from the initial subtheme until the discovery of the main theme which eventually becomes a dimension. Furthermore, based on these findings the dynamics of the cooperation process are then made. Based on the results of preliminary research conducted by Silviandari, Faturochman, and Bakar (in press, 2019), the results of the identification of themes are as follows:

Table 1. Dimensions of cooperation at the individual level

\begin{tabular}{ll}
\hline Dimension & Indicators \\
\hline Relationship Quality & 1. Togetherness \\
\cline { 2 - 2 } & 2. Involvement \\
\cline { 2 - 2 } & 3. Understanding of others \\
\cline { 2 - 2 } & 4. Reciprocal \\
\hline Competence & Self ability \\
\hline The consequences & 1. Achievement of Tasks \\
\cline { 2 - 2 } & 2. Achievement of Material \\
\hline Facilitation & Lighten up the Work \\
\hline Emotions & 1. Positive Emotions \\
\cline { 2 - 2 } & 2. Emotional stability \\
\cline { 2 - 2 } & 3. Emotion Regulation \\
\hline
\end{tabular}

\subsection{The dynamics of cooperation at the individual level}

Relationship quality is one of the important factors that play a role in creating cooperation. Referring to the research results of Silviandari, Faturochman, and Bakar (in press, 2019), relationship quality is indicated in the form of togetherness, involvement, understanding of others, reciprocal relationships, and respect. Relationship quality in the cooperation process can 
stimulate the emergence of one's abilities. Why does this happen? because when individuals feel there is support and acceptance from others in their scope of work, they will tend to have the freedom to actualize their abilities or competencies, for example in the form of pouring out ideas that can be applied at work to help their work. In addition, the existence of quality relations will increase work energy. This is as stated by the participants as follows:

rekan kerja saya menjadi lebih (banyak), saya merasa lebih berkontribusi bagi perusahaan/organisasi, rekan kerja saya bisa melihat progress kerja saya (p.135)

saling memberi dan menerima masukan, tugas cepat selesai..... (p.19)

...koordinasi 2 bagian untuk meningkatkan semangat kerja (p.3)

The results of this study are in line with what was delivered by Deutsch in 1962 that cooperation can motivate mutual trust, exchange resources, and help one another in a continuing effort, so from this process a relationship is formed that characterizes openness, positivity and productivity[3]. While other research that supports the results with this finding is research from West and Smith [1] which shows that cooperation is a useful, supportive, and integrative action which in turn helps the team to succeed in its task and strengthens interpersonal relationships.

Relationship quality is not only an antecedent for the emergence of competence, but it also has an impact on the emergence of emotional aspects in cooperation. It is undeniable when there is a relationship involving two or more people, there will also be a variety of responses and expressions of emotions that accompany it. Both positive and negative emotions. As said by House, Doorn, Heerdink, \& Kleef [16] that a person's emotions can arouse the emotions of others. The results of this study indicate that the effects of relationship quality in a cooperative process are positive emotions, emotional regulation, and emotional stability. Positive emotions are manifested in the form of feelings of pleasure, pride, comfort, satisfaction, and so on. One example is the presence of togetherness that is realized with a familiar atmosphere that makes individuals feel excited and happy at work. This is as expressed by the participants as follows:

akrab, semangat, senang (p.25)

In the process of cooperation, the competencies possessed by each individual will be able to have an impact on achievement, namely the achievement of tasks and the achievement of material. Achievement of the task is manifested in the form of achieving targets, work effectiveness, efficiency, productivity, finding solutions, working safely, managing work. On the other hand, competence also has an impact on material achievement, such as incentives, benefits, and wages.

.... dapat belajar hal baru, kerjaan lebih mudah (p.75)

Selesai tepat waktu, banyak ide yang membantu pekerjaan,...(p.62)

Link bertambah dan tentu saja mendapat profit (p.97)

The results of this study are in line with the findings of Tjosvold [16]where cooperation can consistently strengthen work relations, morals, and can increase productivity, especially on complex tasks. In addition, cooperative groups are considered capable of integrating individuals into the organization so that it can help the organization to be productive.

The consequences in the form of achievement as mentioned above will have an important impact on work. The impact is the emergence of facilitative actions that can facilitate the work so that the work can run smoothly. In turn, this convenience will have an impact on the emergence of positive emotions. This was stated by the participants as follows:

Pekerjaaan cepat selesai dan jadi ringan melakukan sesuatu (p.39) 
Target tercapai, memudahkan pekerjaan (p. 70)

Memudahkan penyelesaian tugas dan hubungan emosional dengan rekan kerja semakin baik (p.1)

Pekerjaan berjalan lancar dan senang (p.10)

On the other hand, the achievements that have been achieved by individuals in the process of cooperation will have an influence on the emotional aspects directly. Individuals feel the emergence of positive emotions that are manifested by feelings of relief, happy and satisfaction when he/she can complete his/her work in accordance with predetermined targets.

Mengurangi masalah yang dihadapi dan merasa lega $(p, 23)$

Senang, pekerjaan selesai tepat waktu (p.49)

Keuntungan satu sama lain, hasil pekerjaan memuaskan (p.139)

Besides positive emotions, the consequences of cooperation in the form of this achievement can also affect emotional stability. The achievement of a work target will be able to encourage the emergence of comfort in work and the reduced burden of thought. This was stated by the participants as follows:

Pekerjaan terselesaikan tepat waktu, suasana kerja lebih nyaman untuk saya...(p.9)

Beban pikiran berkurang, dapat menyusun rencana kerja dengan baik, tidak merasakan tekanan pekerjaan( $p .7)$

In the end, the estuary of cooperation at the individual level is an emotional aspect. The results of previous studies indicate that the dominant emotional aspect coloring the cooperative process is positive emotions. This means that cooperation gives a good influence on the emotional aspects of individuals.

Figure 1. The dynamics of cooperation at the individual level at work

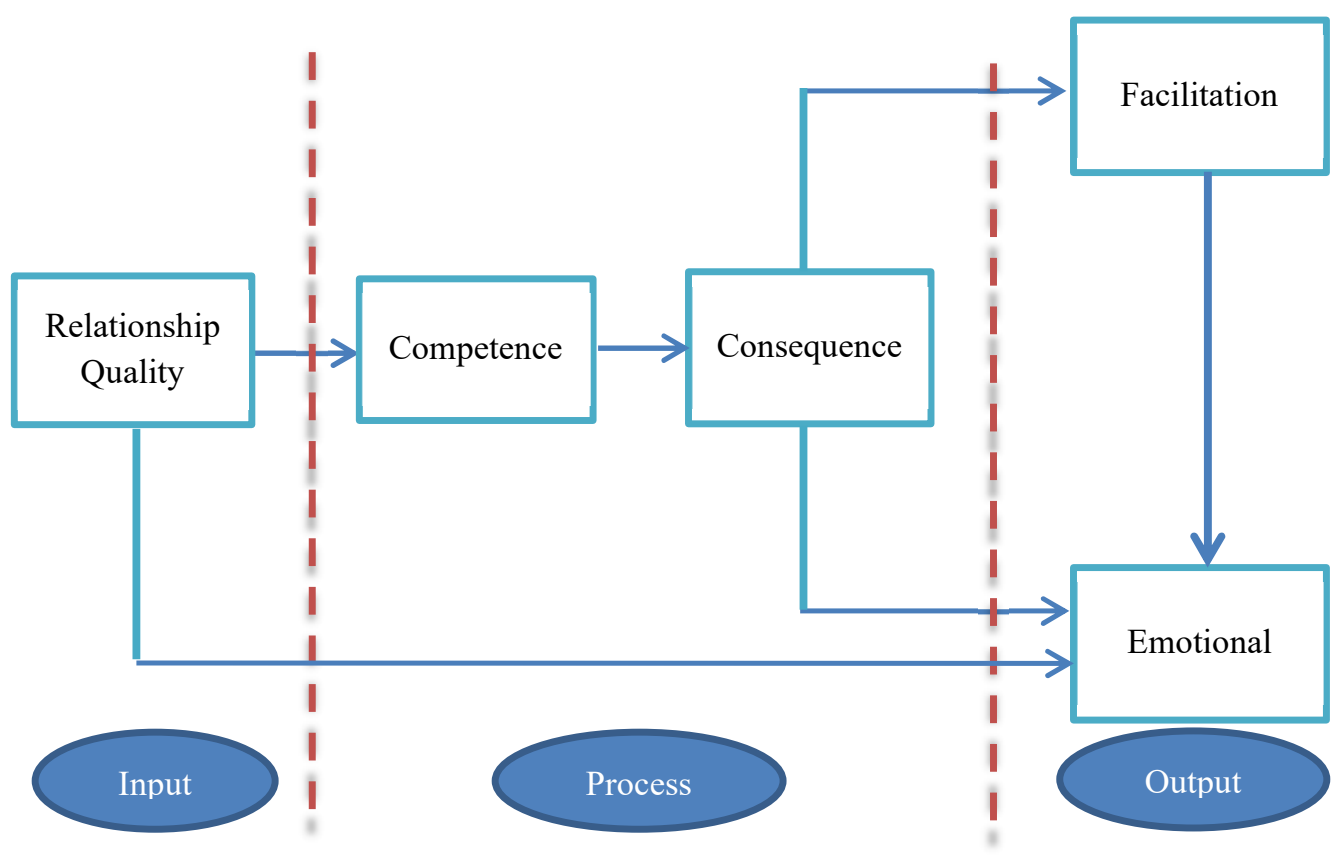




\section{CONCLUSSIONS}

Based on the results of this study it can be concluded that cooperation at the individual level begins to form from the relationship between individuals characterized by togetherness, involvement, understanding in others, reciprocity and respect. This positive action can encourage the emergence of abilities or competencies that support the achievement of consequences in the form of achieving tasks and achieving material. Through this achievement, cooperation can facilitate the task so that the work becomes light, easy, and smooth to do. Not only that, in this study the end of the dynamics of cooperation is the emergence of emotional aspects in the form of positive emotions, emotional regulation and emotional stability.

\section{REFERENCES}

[1] M. A. West, D. Tjosvold, and K. G. Smith, Organizational Teamwork and Cooperative Working International Handbook Of Organizational Teamwork. West Sussex: John Wiley \& Sons Ltd, 2003.

[2] M. Deutsch, "Cooperation and Competition," in International Handbook of Organizational Teamwork and Cooperative Working, M. A. West, D. Tjosvold, and K. G. Smith, Eds. West Sussex: John Wiley \& Sons Ltd, 2003, pp. 9-44.

[3] D. Tjosvold, "Cooperation Theory and Organizations," Hum. Relations, vol. 37, no. (9), pp. 743-767, 1984.

[4] C. C. Chen, X. Chen, and J. R. Meindl, "How Can Cooperation Be Fostered? The Cultural Effects Of Individualism - Collectivism,” Acad. Manag. Rev., vol. 23, no. 2, pp. 285-304, 1998.

[5] D. W. Johnson and R. T. Johnson, "New Developments in Social Interdependence Theory New Developments in Social Interdependence Theory," Genet. Soc. Gen. Psychol. Monogr., vol. 131, no. 4, pp. 285-358, 2005.

[6] F. G. Wallner and M. J. Jandl, Indegenous and Cultural Psychology: Understanding People in Context. United States of America: Springer Science + Bussines Media, Inc., 2006.

[7] Faturochman, W. M. Minza, and T. . Nurjaman, "Pengembangan Ilmu dan Berbagai Pendekatan Indigenous Psychology," Faturochman, W. . Minza, and T. . Nurjaman, Eds. Yogyakarta: Pustaka Pelajar, 2017, pp. 38-54.

[8] D. W. Johnson and R. T. Johnson, Morton Deutsch's Tough-Minded, and Research, no. January. 2018.

[9] S. Gachter and B. Herrmann, "Reciprocity, culture and human cooperation: previous insights and a new cross-cultural experiment," Philos. Trans. R. Soc. B, vol. 365, no. 12, pp. 791-806, 2009.

[10] N. Berigan and K. Irwin, "Culture, Cooperation, and the General Welfare," Soc. Psychol. $Q$. , vol. 74, no. 4, pp. 341-360, 2011.

[11] K. Yuniarti, "Psikologi Indigenous: Saatnya Menentukan Mainstream Keilmuan dari Tanah Air. (Naskah Pidato Pengukuhan Jabatan Guru Besar tidak dipublikasikan).," Yogyakarta, 2013. 
[12] D. L. Gladstein, "Groups in Context: a model of task group effectiveness," Adm. Sci. Q., vol. 29, no. 4, pp. 499-517, 1984.

[13] S. B. Mackenzie, P. M. Podsakoff, and M. Ahearne, "Moderating Effects of Goal Acceptance on the Relationship between Group Cohesiveness and Productivity," J. Appl. Psychol., vol. 82, no. 6, pp. 974-983, 1997.

[14] M. . Korsgaard, H. J. Sapienza, and D. M. Scheiger, "Organizational Justice in Strategic Decision Making," in Justice In The Workplace : From Theory to Practice, C. Rusell, Ed. New jersey: Lawrence Erlbaum Associates Inc., 2001, p. 209=228.

[15] J. W. Creswell, Qualitative Inquiry and Research Design: Choosing Among Five Approaches. USA: Sage PublicationsSage CA: Thousand Oaks, CA, 2013.

[16] M. House, E. A. Van Doorn, M. W. Heerdink, and G. A. Van Kleef, "Emotion and the construal of social situations: Inferences of cooperation versus competition from expressions of anger, happiness, and disappointment Emotion and the construal of social situations : Inferences of cooperation versus competition from exp," Cogn. Emot., vol. 26, no. 3, pp. 442-461, 2012. 